\title{
Correlation of Metabolic Acidosis in Neonate with Morbidity, Mortality and Neurodevelopmental Outcome.
}

\author{
S Srikrishna', Kadukuntla Swapna Reddy², M Ravi Kiran ${ }^{3}$ \\ ${ }^{1}$ Associate professor, Department of Paediatrics, Apollo medical college, Hyderabad, Telangana, ${ }^{2}$ Assistant Professor, Department of Paediatrics, Apollo medical college, \\ Hyderabad, Telangana, ${ }^{3}$ Assistant Professor, Department of Community Medicine, ASRAM medical college, Eluru, A.P.
}

\section{Abstract}

Background: In metabolic acidosis there is risk of neonatal encephalopathy with symptoms varying from lethargy to coma. The neonates with encephalopathy usually present with decreased level of consciousness with abnormality in neuromotor tone and associated with seizure like activity, hypoventilation or apnea. Subjects and Methods: In the present study the children were followed upto 9 months of age and assessment of neurodevelopment was done and the correlation of acidosis with neurodevelopment outcome was analyzed. Results: Of 100 neonates with metabolic acidosis, 26 babies had necrotizing enterocolitis, 20 had seizures, 15 had intraventricular/periventricular hemorrhage and 33 babies had renal dysfunction. Out of 100 neonates with metabolic acidosis, 10 babies died and 23 had good outcome. There exists correlation between $\mathrm{pH}$ and neurodevelopmental outcome. The $\mathrm{p}$ value is 0.000 i.e it is significant. Thus with decreasing $\mathrm{pH}$, there is increased incidence of neurodevelopmental delay. The incidence of developmental delay is more in neonates with $\mathrm{pH}<7.20,4(21.1 \%)$ babies had transient abnormalities, $2(10.5 \%)$ had persistent abnormalities. There exists correlation between base deficit and neurodevelopmental outcome. The $\mathrm{p}$ value is 0.000 i.e it is significant. Thus with increasing base deficit, there is increased incidence of neurodevelopmental delay. Conclusion: With based deficit of $>12 \mathrm{mmol} / \mathrm{l}$, there is increased incidence of neurodevelopmental delay i.e $25 \%$ had persistent abnormality and $10 \%$ transient abnormality hence it can be used as one of the early predictors of neurodevelopmental delay.

Keywords: Base deficit, Metabolic Acidosis, Neurodevelopment, Neonates.

Corresponding Author: Dr. Kadukuntla Swapna Reddy, Assistant Professor, Department of Paediatrics, Apollo medical college, Hyderabad, Telangana.

Received: February 2019

Accepted: February 2019

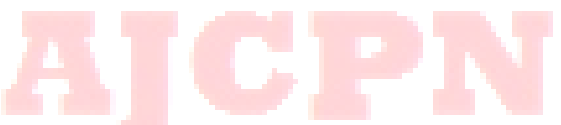

\section{Introduction}

Acidemia is common in neonates especially in association with prematurity and perinatal asphyxia. Metabolic acidosis in preterm infants may be associated with hypoxemia, hypotension or poor tissue perfusion, anemia, infection or sepsis, or strenuous activity (respiratory distress). There is an association between acidosis, acute physiological dysfunction in the neonate and longer term neurodevelopmental abnormalities. Whether the acidosis is causative or only associated with acute organ dysfunction and abnormal neurodevelopment is less certain. ${ }^{[1,2]}$

Metabolic Acidosis results from either inability of the kidney to excrete the dietary $\mathrm{H}+$ load or increase in the generation of $\mathrm{H}+$ or loss of bicarbonate. Base Excess is a useful parameter which reflects metabolic component of abnormality under steady state conditions. The presence or absence of increased anion gap is useful for determining the cause of metabolic acidosis. ${ }^{[3]}$

Metabolic acidosis associated with normal anion gap results from buffer loss through the renal or gastro intestinal systems. Bicarbonate is replaced by chloride and serum chloride is elevated. Increased production of non-volatile acids in the body such as phosphate, sulfate or organic acids titrates bicarbonate and leads to metabolic acidosis. Subsequently, inadequate hydrogen ion excretion by premature kidney results in acidosis. Metabolism of sulfur containing aminoacids in casein and increased hydrogen ion release due to rapid mineralization of bone cause an increased acid load. ${ }^{[4]}$

Birth asphyxia is most common cause of metabolic acidosis. In asphyxia initially there is redistribution of cardiac output with an increased proportion going to brain, heart and adrenal glands. Impaired cerebral blood flow results in anaerobic metabolism and eventually intracellular energy failure due to increase in the utilization of glucose in the brain and fall in the concentration of glycogen, phosphocreatine and ATP. This energy failure impairs ion pump function resuling in accumulation of intracellular $\mathrm{Na}+$, $\mathrm{Cl}, \mathrm{HCO} 3 \& \mathrm{Ca}+2$, excitatory aminoacid neurotransmitters like glutamate. ${ }^{[5,6]}$

Failure of $\mathrm{Na}+/ \mathrm{K}+$ ATPase pump leads to influx of $\mathrm{Na}+$ and $\mathrm{Ca}+2$ with osmotic influx of water causing neuronal edema. Activation of receptor subtypes such as kainate, NMDA, AMPA by glutamate released allow $\mathrm{Ca}+2$ to enter the 
neurons. $\mathrm{Ca}+2$ ions inside the cells cause activation of intracellular proteases and lipases with generation of $\mathrm{O} 2$ free radicals causing further damage to cellular membranes exacerbating neuronal damage. Thus neonatal acidosis and hypoxia have their main effect on the central nervous system and in preterm infants leads to periventricular leukomalacia. ${ }^{[6-8]}$

Evaluation of neuromotor function is of paramount importance in establishing links between perinatal events and late outcome. Changes in neuromotor function observed during first year of life seem closely linked with maturation of central nervous system and with presence or absence of brain damage. Moreover these changes are relatively independent of familial and sociocultural background and quality of parent-infant interaction. Therefore it is useful to obtain information on the neuromotor function to document perinatal origins of a later dysfunction or to demonstrate the effect of early intervention and recovery from injury. Neuromotor retardation may occur due to gestational immaturity, perinatal hypoxia, birth trauma, metabolic disorders, hypoglycemia, Kernicterus, intra-uterine infections, postnatal CNS infections, hypothyroidism, developmental and chromosomal disorders. ${ }^{[9,10]}$

In hypoxic neonates due to anaerobic metabolism lactic acid accumulation results in metabolic acidosis. In metabolic acidosis there is risk of neonatal encephalopathy with symptoms varying from lethargy to coma. The neonates with encephalopathy usually present with decreased level of consciousness with abnormality in neuromotor tone and associated with seizure like activity, hypoventilation or apnea, depressed primitive reflexes like moro's reflex, suck reflex etc. ${ }^{[11]}$

In the present study we are using AMIEL-TISON.C, a method for neurological evaluation within the first year of life. It helps to identify at the end of the first year the children with no abnormality, patterns of transient abnormalities and patterns of persistent abnormalities.

There are many studies done on neonatal acidemia and base deficit by collecting umbilical cord arterial blood and correlation of neonatal acidosis with morbidity and mortality but there are only few studies done by collecting arterial blood sample. This is a follow up study where the children were followed upto 9 months of age and assessment of neurodevelopment was done and the correlation of acidosis with neurodevelopment outcome was analyzed.

\section{Objectives:}

1. To study the correlation between metabolic acidosis and morbidity in neonates.

2. To study the correlation between metabolic acidosis in neonate and neurodevelopmental outcome.

3. To study the correlation between severity of acidosis and occurrence of neurodevelopmental delay.

\section{Subjects and Methods}

Neonates below 48hrs of life admitted to NICU of Pragna Children's Hospital with symptoms of acidosis and in whom
ABG done at the time of admission showing $\mathrm{pH}<7.35$ and base excess $<-4 \mathrm{mmol} / \mathrm{l}$ or base deficict $>4 \mathrm{mmol} / \mathrm{l}$ were included in the study group. The base excess is used for the assessment of the metabolic component of acid-base disorders, and indicates whether the patient has metabolic acidosis or metabolic alkalosis.

A typical reference range for base excess is -2 to $+2 \mathrm{mmol} / \mathrm{l}$. A base deficit (a below-normal base excess), thus indicates metabolic acidosis.

The neonates with respiratory acidosis are excluded. Respiratory acidosis defined as $\mathrm{pCO} 2>50 \mathrm{mmHg}$ and $\mathrm{PH}<7.35$.

In NICU detailed history and thorough clinical examination was done. $1 \mathrm{ml}$ of Arterial blood is collected in heparinised syringe and sent to the lab. Other investigations like Bloodurea, S.creatinine, S.electrolytes, CBP, CRP were done along with certain special investigations like NSG, 2DECho, EEG , CT Scan Brain as and when required to establish the final diagnosis. The neonates, then were followed up, at 3 months, 6months and 9 months of age to assess the neurodevelopment by detailed neurological examination and Amiel Tison method of neurological assesment and find out any neuro developmental delay and its correlation with metabolic acidosis.

All neonates presenting with clinical features of acidosis and ABG done at admission showing $\mathrm{pH}$ of $<7.35$ and base deficit of $>4 \mathrm{mmol} / \mathrm{l}$ were includes and Neonates with Congenital anomalies, Inborn errors of metabolism, Congenital heart disease, ELBW $<1 \mathrm{~kg}$, Gestational age of $<30$ wks were excluded from the present study.

Arterial blood is collected from peripheral artery after cleaning the site with povidone iodine and spirit. $1 \mathrm{ml}$ of blood is collected in heparinised syringe and sent immediately to the lab. The outcome measures in the present study was morbidity, neurodevelopmental outcome, mortality and good outcome

\section{Results}

In the present study a total of 110 neonates were enrolled. Of 110 neonates, 10 babies lost follow up. Thus in the final study, a sample of 100 neonates were analyzed.

The babies who presented with clinical features of acidosis within $48 \mathrm{hrs}$ of life were selected. In these babies ABG was done at the time of admission. The babies in whom ABG showed $\mathrm{pH}<7.35$ and base deficit of $>4 \mathrm{mmol} / \mathrm{l}$ were selected for the study.

Out of 100 neonates, 19 babies had $\mathrm{pH}<7.20$, 46 babies had $\mathrm{pH}$ 7.20-7.25 and 35 babies had $\mathrm{pH}$ 7.25.

Out of 100 neonates , 50 babies had base deficit of $4-8$ $\mathrm{mmol} / \mathrm{l}, 30 \mathrm{babies}$ had base deficit of $8-12 \mathrm{mmol} / \mathrm{l}$ and 20 babies had base deficit of $>12 \mathrm{mmol} / \mathrm{l}$. 
Table 1: Distribution based on $\mathrm{pH}$.

\begin{tabular}{|l|l|}
\hline $\mathbf{p H}$ & Frequency \\
\hline$<7.20$ & 19 \\
\hline $7.20-7.25$ & 46 \\
\hline$>7.25$ & 35 \\
\hline Total & 100 \\
\hline
\end{tabular}

Table 2: Distribution based on base deficit

\begin{tabular}{|l|l|}
\hline Base deficit & Frequency \\
\hline $4-8 \mathrm{mmol} / \mathrm{l}$ & 50 \\
\hline $8-12 \mathrm{mmol} / \mathrm{l}$ & 30 \\
\hline$>12 \mathrm{mmol} / \mathrm{l}$ & 20 \\
\hline Total & 100 \\
\hline
\end{tabular}

Of total 100 neonates with metabolic acidosis , 54 ( 54\%) were male babies and 46 ( $46 \%$ ) were female babies.

\begin{tabular}{|c|c|c|c|c|}
\hline \multicolumn{5}{|c|}{ Table 3: Distribution as per gender based on pH } \\
\hline & & \multicolumn{2}{|c|}{ Gender } & \multirow[t]{2}{*}{ Tota } \\
\hline & & Female & Male & \\
\hline \multirow[t]{3}{*}{$\mathrm{pH}$} & $<7.20$ & $6(31.6 \%)$ & $13(68.4 \%)$ & 19 \\
\hline & $7.20-7.25$ & $18(39.1 \%)$ & $28(60.9 \%)$ & 46 \\
\hline & $>7.25$ & $22(62.9 \%)$ & $13(37.1 \%)$ & 35 \\
\hline \multicolumn{2}{|c|}{ Total } & 46 & 54 & 100 \\
\hline
\end{tabular}

Of 19 babies who had $\mathrm{pH}<7.20,6$ ( $31.6 \%)$ babies were female and 13 ( $68.4 \%$ ) babies were male. Of 46 babies who had $\mathrm{pH} 7.20-7.25,18$ ( $39.1 \%$ ) were female and 28 (60.9\% ) were male. Of 35 babies who had $\mathrm{pH}>7.25,22$ ( $62.9 \%$ ) were female babies and 13 ( $37.1 \%$ ) were male babies. There is no correlation between $\mathrm{pH}$ and gender. The $p$ value is 0.039 i.e it is not significant.

Table 4: Distribution as per gender based on base deficit

\begin{tabular}{|l|l|l|l|l|}
\hline \multicolumn{2}{|c|}{} & \multicolumn{2}{|l|}{ Gender } & \multirow{2}{*}{ Total } \\
\cline { 3 - 4 } \multicolumn{2}{c|}{} & Female & Male & \\
\hline \multirow{3}{*}{$\begin{array}{l}\text { Base } \\
\text { Deficit }\end{array}$} & $4-8 \mathrm{mmol} / 1$ & $23(46 \%)$ & $27(54 \%)$ & 50 \\
\cline { 2 - 4 } & $8-12 \mathrm{mmol} / 1$ & $17(56.7 \%)$ & $13(43.3 \%)$ & 30 \\
\cline { 2 - 4 } & $>12 \mathrm{mmol} / 1$ & $6(30 \%)$ & $14(70 \%)$ & 20 \\
\hline \multicolumn{2}{|l|}{ Total } & 46 & 54 & 100 \\
\hline
\end{tabular}

Of 100 neonates with metabolic acidosis, 26 babies had necrotizing enterocolitis, 20 had seizures, 15 had intraventricular/periventricular hemorrhage and 33 babies had renal dysfunction. Out of 100 neonates with metabolic acidosis, 10 babies died and 23 had good outcome.

Around 14 babies with morbidity had more than one outcome, 3 babies had more than two outcomes and 1 baby had more than three outcomes Of 19 babies who had $\mathrm{pH}<7.20,7$ (36.8\% ) babies had seizures. Of 46 babies who had pH 7.20-7.25, 10 ( $21.7 \%$ ) babies had seizures. .Of 35 babies who had $\mathrm{pH}>7.25,3(8.6 \%)$ babies had seizures. There is no correlation between $\mathrm{pH}$ and seizures. The $\mathrm{p}$ value is 0.043 i.e it is not significant.

Of 50 babies who had base deficit of $4-8 \mathrm{mmol} / \mathrm{l}, 3$ ( $6 \%$ ) babies had seizures. Of 30 babies who had base deficit of 8 - $12 \mathrm{mmol} / \mathrm{l}, 10$ (33.3\%) babies had seizures. Of 20 babies who had base deficit of $>12 \mathrm{mmol} / \mathrm{l}, 7$ (35\%) babies had seizures. There exists correlation between base deficit and seizures. The $p$ value is 0.001 i.e it is significant.

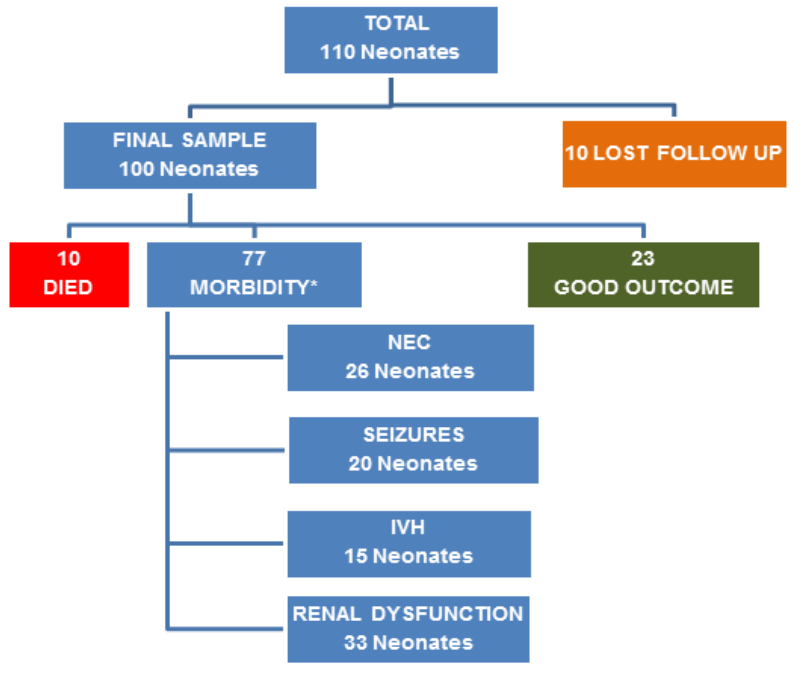

Of 50 babies who had base deficit of $4-8 \mathrm{mmol} / \mathrm{l}, 2$ (4\%) babies had intraventricular/periventricular hemorrhage. Of 30 babies who had base deficit of $8-12 \mathrm{mmol} / \mathrm{l}, 9$ (30\%) babies had intraventricular/periventricular hemorrhage. Of 20 babies who had base deficit of $>12 \mathrm{mmol} / \mathrm{l}, \quad 4$ (20\%) babies had intraventricular/periventricular hemorrhage.

There is no correlation between base deficit and intraventricular / periventricular hemorrhage. The $\mathrm{p}$ value is 0.005 i.e it is not significant

Of 19 babies who had $\mathrm{pH}<7.20,3(15.8 \%)$ babies had necrotizing enterocolitis. Of 46 babies who had $\mathrm{pH} 7.20$ $7.25,9(19.6 \%)$ babies had necrotizing enterocolitis. Of 35 babies who had $\mathrm{pH}>7.25, .14$ (40\%) babies had necrotizing enterocolitis. There is no correlation between $\mathrm{pH}$ and necrotizing enterocolitis. The $\mathrm{p}$ value is 0.061 i.e it is not significant.

Of 19 babies who had $\mathrm{pH}<7.20,3$ (15.8\%) babies had renal dysfunction. Of 46 babies who had $\mathrm{pH} 7.20-7.25,21$ ( $45.7 \%$ ) babies had renal dysfunction. Of 35 babies who had $\mathrm{pH}>7.25,9(25.7 \%)$ babies had renal dysfunction.

Of 19 babies who had $\mathrm{pH}<7.20$, not even a single baby had good outcome. Of 46 babies who had $\mathrm{pH}$ 7.20-7.25, 8 ( $17.4 \%$ ) babies had good outcome. Of 35 babies who had $\mathrm{pH}>7.25,15$ ( 42.9\%) babies had good outcome.

Of 50 babies who had base deficit of $4-8 \mathrm{mmol} / \mathrm{l}$, not even a single baby died. Of 30 babies who had base deficit of 8 $-12 \mathrm{mmol} / \mathrm{l}, 3$ ( $10 \%$ ) babies died. Of 20 babies who had base deficit of $>12 \mathrm{mmol} / \mathrm{l}, 7$ ( $35 \%$ ) babies died.

\section{Discussion}

In the present study, 100 neonates were enrolled. Both term and preterm neonates were included. Preterm babies were more in each group. But the pvalue $(0.649 / 0.630)$ is not 
significant. There is no correlation between gestational age and $\mathrm{pH} \&$ base deficit.

In the study conducted by Victory $\mathrm{R}$ et al, ${ }^{[12]}$ had concluded that umbilical cord $\mathrm{pH}$ and B.E are related to subsequent adverse outcome events for infants delivered very preterm. Worsening acidosis is associated with progressively greater increase in these outcomes. In the study conducted by Salhab and Perlman, ${ }^{[13]}$ had concluded that the larger depressed preterm infant is at increased risk for moderate to severe encephalopathy.

Table 5: Correlation between $\mathrm{pH}$ and neurodevelopmental outcome

\begin{tabular}{|c|c|c|c|c|c|c|}
\hline & \multicolumn{4}{|c|}{ Neurodevelopment } & \multirow[t]{2}{*}{ Total } \\
\hline & & Died & No Abn & PA & TA & \\
\hline \multirow[t]{6}{*}{$\mathrm{pH}$} & \multirow[t]{2}{*}{$<7.20$} & 9 & 4 & 2 & 4 & 19 \\
\hline & & $47.4 \%$ & $21.1 \%$ & $10.5 \%$ & $21.1 \%$ & $100.0 \%$ \\
\hline & \multirow[t]{2}{*}{$7.20-7.25$} & 1 & 37 & 6 & 2 & 46 \\
\hline & & $2.2 \%$ & $80.4 \%$ & $13.0 \%$ & $4.3 \%$ & $100.0 \%$ \\
\hline & \multirow[t]{2}{*}{$>7.25$} & 0 & 33 & 1 & 1 & 35 \\
\hline & & $.0 \%$ & $94.3 \%$ & $2.9 \%$ & $2.9 \%$ & $100.0 \%$ \\
\hline \multirow{2}{*}{\multicolumn{2}{|c|}{ Total }} & 10 & 74 & 9 & 7 & 100 \\
\hline & & $10.0 \%$ & $74.0 \%$ & $9.0 \%$ & $7.0 \%$ & $100.0 \%$ \\
\hline
\end{tabular}

*No Abn - No Abnormality, TA - Transient abnormality, PA - Persistent abnormality

Table 6: Correlation between base deficit and neurodevelopmental outcome.

\begin{tabular}{|c|c|c|c|c|c|c|}
\hline & \multicolumn{4}{|c|}{ Neurodevelopment } & \multirow[t]{2}{*}{ Total } \\
\hline & & Died & NoAbn & PA & TA & \\
\hline \multirow{6}{*}{$\begin{array}{l}\text { Base } \\
\text { Deficit }\end{array}$} & \multirow[t]{2}{*}{$4-8 \mathrm{mmol} / \mathrm{l}$} & 0 & 47 & 2 & 1 & 50 \\
\hline & & $.0 \%$ & $94.0 \%$ & $4.0 \%$ & $2.0 \%$ & $100.0 \%$ \\
\hline & \multirow{2}{*}{$8-12 \mathrm{mmol} / \mathrm{l}$} & 3 & 21 & 2 & 4 & 30 \\
\hline & & $10.0 \%$ & $70.0 \%$ & $6.7 \%$ & $13.3 \%$ & $100.0 \%$ \\
\hline & \multirow[t]{2}{*}{$>12 \mathrm{mmol} / \mathrm{l}$} & 7 & 6 & 5 & 2 & 20 \\
\hline & & $35.0 \%$ & $30.0 \%$ & $25.0 \%$ & $10.0 \%$ & $100.0 \%$ \\
\hline \multirow{2}{*}{\multicolumn{2}{|c|}{ Total }} & 10 & 74 & 9 & 7 & 100 \\
\hline & & $10.0 \%$ & $74.0 \%$ & $9.0 \%$ & $7.0 \%$ & $100.0 \%$ \\
\hline
\end{tabular}

*No Abn - No Abnormality, TA - Transient abnormality, PA - Persistent abnormality

In the present study, there is no correlation between gender and $\mathrm{pH} \&$ base deficit. Of total 100 neonates with metabolic acidosis, 54 were male babies and 46 were female babies. But in each group of $\mathrm{pH}$ and base deficit, the incidence varied. There is no correlation between $\mathrm{pH}$, base deficit and gender. The p-value for the gender and $\mathrm{pH} \&$ base deficit is 0.039 and 0.179 respectively i.e it is not significant.

In a study conducted by Anne Lisbeth Hoffmann et al, ${ }^{[14]}$ a total of 2778 infants born at term were studied to determine relationship between APGAR scores after 1 min, umbilical artery $\mathrm{pH}$ values, mode of delivery, diagnosis of fetal distress leading to operative delivery and sex of the neonate. A significantly higher incidence of operatively delivered for fetal distress and acidosis was found in boys i.e 58.4\%.

In a study conducted by Hassan et $\mathrm{al},{ }^{[15]}$ in which nucleated red blood cell was used for early diagnosis of perinatal asphyxia had the incidence of acidosis more in male babies i.e $63 \%$.
In the present study, there is increased incidence of seizures in neonates with base deficit $>8 \mathrm{mmol} / \mathrm{l}(35 \%)$ and $\mathrm{pH}<7.20$ $(36.8 \%)$. There is correlation between base deficit and seizures. The $\mathrm{p}$ value for seizures and base deficit is 0.001 i.e it is significant.

There is correlation between $\mathrm{pH}$, base deficit and mortality. The $\mathrm{p}$ value for the mortality and $\mathrm{pH} \&$ base deficit is 0.000 and 0.000 respectively i.e it is not significant. Of 19 babies who had $\mathrm{pH}<7.20,9$ (47.4\%) babies died. Of 46 babies who had $\mathrm{pH} 7.20-7.25,1$ (2.2\%) baby died .Of 35 babies who had $\mathrm{pH}>7.25$, not even a single baby died. Of 50 babies who had base deficit of $4-8 \mathrm{mmol} / \mathrm{l}$, not even a single baby died. Of 30 babies who had base deficit of $8-12 \mathrm{mmol} / \mathrm{l}, 3$ $(10 \%)$ babies died. Of 20 babies who had base deficit of $>12$ $\mathrm{mmol} / \mathrm{l}, 7$ (35\%) babies died.

R.L.Andres et al, ${ }^{[16]}$ conducted a study that concluded that the metabolic component of fetal academia i. e umbilical artery $\mathrm{pH}<7.0$, base deficit, and bicarbonate are most important variables in subsequent neonatal morbidity i.e IVH, RDS, NEC, sepsis. Low umbilical artery $\mathrm{pH}<7.0$ associated with HIE, cardiopulmonary resuscitation, intubation and IUGR. Greater mean base deficit was associated with seizure, cardiopulmonary resuscitation, IUGR and HIE.

Sehdev HM et al, ${ }^{[17]}$ conducted a case-control study in which both of them had umbilical artery $\mathrm{pH}<7$. Cases were defined as those who had seizures, IVH, RDS, sepsis, GI complications and death. Controls had no complications. Out of 35 cases 3 neonatal deaths, 2 had IVH, 5 had GI dysfunction, 4 had neonatal seizures. Neonatal morbidity in neonates with umbilical artery cord $\mathrm{pH}<7$ can be predicted by a high arterial base deficit value and low 5 minute APGAR score.

Belai et al had reported that an arterio-venous pCO2 difference $>25$ torr was a highly sensitive parameter to identify asphyxiated infants with seizures, HIE, cardio pulmonary and renal dysfunction. ${ }^{[18]}$

There exists correlation between $\mathrm{pH}$ and neurodevelopmental outcome. The p value is 0.000 i.e it is significant .Thus with decreasing $\mathrm{pH}$, there is increased incidence of neurodevelopmental delay. The incidence of developmental delay is more in neonates with $\mathrm{pH}<7.20,4$ $(21.1 \%)$ babies had transient abnormalities, $2(10.5 \%)$ had persistent abnormalities.

There exists correlation between base deficit and neurodevelopmental outcome. The p value is 0.000 i.e it is significant. Thus with increasing base defict, there is increased incidence of neurodevelopmental delay. With based deficit of $>12 \mathrm{mmol} / \mathrm{l}$, there is increased incidence of neurodevelopmental delay i.e $25 \%$ had persistent abnormality and $10 \%$ transient abnormality.

Helene $\mathrm{T}$ et al conducted neurodevelopmental assessment in children born with an umbilical artery $\mathrm{pH}<7.0$ infants were enrolled. From this group 23 were admitted in NICU and 8 required intubation. 28 survived neonatal period, 3 children 
experienced an episode of mild hypertonia, and one child had mild motor developmental delay. ${ }^{[19]}$

Lavrijsen et al had conducted a study to determine the effects of academia at birth on neurodevelopment in preterm and fullterm neonates. Acidemia at birth increased the occurrence of severe intraventricular hemorrhage in preterm neonates and seizures in both preterm and full term neonates. However no significant effect of acidemia on longterm outcome could be demonstrated. ${ }^{[20]}$

Wildschut $\mathrm{J}$ et al had conducted study to assesss the relationship between acid-base status and quality and quantity of general movements at birth and at age 3 months and motor, cognitive and behavioural functioning at age of 4 yrs. The study concluded that in a sample of infants with a large variation in umbilical artery $\mathrm{pH}$ and without severe neonatal neurological abnormalities, acid base status at birth and quality of general movements at 3 months of age is not predictive for motor milestone achievement, cognitive and behavioural functioning at 4 yrs but these parameters are related to a less optimal condition of nervous system.[21]

\section{Limitations of the Study}

In the present study the babies were followed upto 9 months of age using AMIEL-TISON method of neurodevelopmental assessment. Hence only motor developmental delay could be assessed. Thereby the neonates need to be followed for longer period, atleast for 2 years of age using another scale for neuro development assessment so that even cognitive, language, behavioural developmental delay can be assessed.

\section{Conclusion}

Neuro developmental delay is difficult to predict at birth sometimes inspite of signs of neurological injury. Many parameters are used to predict so that early intervention can be started. Acid base imbalance at birth can be one of the important tools to predict neurodevelopmental delay as base deficit of $>12 \mathrm{mmol} / \mathrm{L}$ is found to have increased incidence i.e $25 \%$ had persistent abnormality and $10 \%$ had transient abnormality.

\section{References}

1. Gale A. Pearson : Fluid, electrolyte and Acid-base distutbances . In : Neil Mc Intosh, Peter Helms and Rosalind Smyth : Forfar \& Arneil's textbook of pediatrics, 7th edition 2008. 535-37.

2. Williams AW, Smith R . Current status of fluid, electrolyte and acidbase disturbances in the neonate. Ann Perinatol Neonatal Care 1997 ; $13: 234-46$.

3. Larry A Greenbaum . Acid- base balance . In : Kliegman, Behrman, Jenson, Stanton : Nelson textbook of pediatrics, 18th edition, vol 1 , $2008: 718-20$.
4. Fawer CL : Maturation of renal function in term and premature neonates. Helv Paediatr Acta 34:11, 1979.

5. Elizabeth G. Doherty and Charles F. Simmons, Jr . Fluid and Electrolyte management . In : John P. Cloherty, Eric C. Eichenwald, Ann R. Stark . Manual of Neonatal Care, 6th edition, 2008 , 107-8.

6. Lisa M. Adcock and Lu Ann Papile . Perinatal asphyxia . In : John P. Cloherty , Eric C. Eichenwald , Ann R. Stark . Manual of Neonatal Care, 6th edition , 2008, 519, 522-24, 527.

7. Ira Adams, Chapman and Barbara J. Stoll . Hypoxia - Ischemia . In : Kliegman , Behrman, Jenson, Stanton : Nelson textbook of pediatrics, 18th edition, vol 1, 2008: 718-20.

8. James Tootey. Perinatal Asphyxia and Hypoxic - ischemic encephalopathy . In : Neil Mc Intosh, Peter Helms and Rosalind Smyth : Forfar \& Arneil's textbook of pediatrics, 7th edition 2008. 204-6.

9. Fee SC, Malee K, Deddish R, Minoque JP , Socol MC . Severe acidosis and subsequent neurologic status . Am J Obstet Gynecol. 1990 Mar ; 162(3) : 802-6.

10. Janet Renate . Neurodevelopmental outcome . In : Forfar \& Arneil's Textbook of Pediatrics, 7th edition, 2008 : 239-41.

11. Shah PS , Raju NV, Beyene J, Perlman M. Recovery of metabolic acidosis in term infants with postasphyxial hypoxic-ischemic encephalopathy . Acta Paediatr. 2003 Aug ; 92(8) : 941-7.

12. Victory R, Penava D, Da Silva O, Natale R, Richardson B. Umbilical cord $\mathrm{pH}$ and base excess values in relation to adverse outcome events for infants delivering at preterm. Am J Obstet Gynecol . 2003 Sep ; 189(3) : 803-7.

13. Salhab WA, Perlamn JM . Severe fetal academia and subsequent neonatal encephalopathy in the larger premature infant . Pediatr Neurol 2005 Jan ; 32 (1) : 25-9.

14. Anne Lisbeth Hoffmann, JesperHjortdal, Niels Jorgan Secher and Birgitte Weile . The relationship between Apgar score, umbilical artery ph and operative delivery for fetal distress in infants born at term. Eur J Obstet Gynecol Reprod Biol. 1991 Jan ; 38(2) : 97-101.

15. Hassan, Gholamali, Mohammad Hadi Sadeghian . Early diagnosis of perinatal asphyxia by nucleated red blood cell count . Archives of Iranian Medicine . $2010 \mathrm{Jul}$; 13(4) : 275-280

16. Andres RL, Saade G, Gilstrap LC, Wilkins I, Witlin A, Zlatnik F, Hankins GV. Association between umbilical blood gas parameters and neonatal morbidity and death in neonates with pathologic fetal acidemia. Am J Obstet Gynecol . 1999 Oct ; 181(4) : 867-71

17. Sehdev HM, Stamilio DM, Macones GA, Graham E, Morgan MA . Predictive factors for neonatal morbidity in neonates with an umbilical arterial cord pH less than 7.00. Am J Obstet Gynecol . 1997 Nov ; 177(5) : 1030-4.

18. Belai Y, Goodwin TM , Durand M, Greenspoon JS , Paul RH , Walther FJ . Umbilical arteriovenous $\mathrm{PO} 2$ and $\mathrm{PCO} 2$ differences and neonatal morbidity in term infants with severe acidosis. Am J Obstet Gynecol. 1998 Jan ; 178(1 Pt 1 ) : 13-9.

19. Nagel HT, Vandenbussche FP, Oepkes D , Jennekens-Schinkel A, Laan LA, Gravenhorst JB . Follow-up of children born with an umbilical arterial blood $\mathrm{pH}<7$. Am J Obstet Gynecol. 1995 Dec;173(6):1758-64.

20. Lavrijsen SW, Uiterwaal CS, Stigter RH, deVries LS, Visser GH, Groenendaal F. Severe umbilical cord academia and neurological outcome in preterm and full-term neonates. Biol Neonate. $2005 ; 88(1)$ :27-34.

21. Wildschut J, Feron FJ , Hendriksen JG, van hall M, GavilanesJiminez , Hadders-Algra M, Vles JS . Acid-base status at birth, spontaneous motor behaviour at term and 3 months and neurodevelopmental outcome at age 4 years in full-term infants. Early Hum Dev. 2005 Jun; 81(6): 535-44. 
Copyright: () the author(s), 2019. It is an open-access article distributed under the terms of the Creative Commons Attribution License (CC BY 4.0), which permits authors to retain ownership of the copyright for their content, and allow anyone to download, reuse, reprint, modify, distribute and/or copy the content as long as the original authors and source are cited.

How to cite this article: Srikrishna S, Reddy KS, Kiran MR. Correlation of Metabolic Acidosis in Neonate with Morbidity, Mortality and Neurodevelopmental Outcome. Asian J. Clin. Pediatr. Neonatol.2019;7(1):40-45.

DOI: dx.doi.org/10.21276/ajcpn.2019.7.1.10

Source of Support: Nil, Conflict of Interest: None declared. 